Catholic educational institutions in Newfoundland. This issue will be seized upon, no doubt, despite its irrelevance to the question, by opponents of denominationalism. It is fortunate, therefore, that this book, which provides a useful starting point for intelligent debate and discussion of the place of denominational education in Newfoundland, is available. The book contributes also to our deliberation on the wider question, so cogently discussed in Amy Gutmann's Democratic Educalion, of the cost and value of educational pluralism in a free and democratic society.

Robert Nicholas Bérard

Dalhousie University

Udo Arnold, ed. Zur Bildungs- und Schulgeschichte Preussens. Tagungsberichte der historischen Kommission für Ost- und Westpreussische Landesforschung. Vol. 8. Lüneburg: Verlag Nordostdeutsches Kulturwerk, 1988. Pp. 132. 30 DM.

In the aftermath of World War II, as in the years following the Versailles Treaty of 1919, much German scholarship devoted to the history of the disputed borderlands between Germany and Poland had strong revanchist overtones. During the 1960 s and '70s, many historians more critical of the German past focused on the harsh treatment of the Polish minority in Prussia after the creation of the German Empire by Bismarck in 1871. This slim anthology illustrates how in recent years the easing of political tensions in central Europe and the increase in scholarly contacts have contributed to a more dispassionate examination of the history of this ethnically mixed region.

The Prussia referred to in the title is not the German state of that name, but rather its provinces of East Prussia (the original duchy with its capital at Königsberg/Kaliningrad), West Prussia (obtained in the first "partition" of Poland in 1772 and including the city of Danzig/Gdansk), and South Prussia or Posen/Poznan (obtained in the second "partition" in 1793 and re-acquired after the Napolconic wars).

In the first essay, Karl-Ernst Jeismann, long active in international efforts to purge nationalist and racist prejudices from history textbooks, provides a general introduction to Prussian educational policies in the late eighteenth and early nineteenth centuries. Summarizing much recent scholarship, Jeismann downplays the uniqueness of the reforms initiated by Wilhclm von Humboldt in 1809-1810 and stresses instead the gradual strengthening of the state's role in educational administration from the 1770 s onward. In this way, he is able to link Prussian developments with Maria Theresa's Schulordnung of 1774 in Austria and with the Polish Education Commission established in the wake of the first partition.

In the most interesting contribution to the anthology, Gregor Harzheim compares the efforts of this Polish Education Commission to "modernize" the country after the shock of the first partition with Prussian efforts to integrate the Polish 
territories gained in 1772 and 1793. The Polish Commission originally advocated the radical step of a common elementary school for all social classes, but this policy was abandoned already by 1783 . Property seized from the disbanded Jesuit order was expended mostly on secondary education, with the government relying on noble and clerical patrons for what expansion occurred in the number of elementary schools. In contrast, Prussian officials devoted more attention to the creation of new elementary schools, especially on the royal domains. Existing schools were not significantly transformed, and, as Harzheim notes, there was no effort to Germanize the population through the elimination of Polish from the schools.

The other two contributions have less to offer. Heinz Lingenberg provides litle more than an outline of the history of educational institutions in Danzig until 1900, with a particular focus on secondary schools for boys. Lieselotte Kunigk-Helbing examines the schools for the Polish minority in Ermland, an ethnically mixed section of East Prussia that remained part of Germany after a plebiscite in 1920. She notes that although the Polish minority in Germany, in contrast to the German minority in reconstituted Poland, did not have its rights guaranteed by the Versailles Treaty, the constitution of the Weimar Republic did grant all minorities the right to use their mother tongues in school and the courts. Although, under the Nazis, graduates of the Polish-language schools increasingly had difficulty obtaining jobs, a new Polish secondary school was founded in the town of Marienwerder as late as 1937-only to be closed in the week before Hitler's attack on Poland in 1939.

No contribution to the anthology examines the more thoroughly explored period of persecution of the Polish minority during the Second Empire. Readers interested in this might turn to the summary in Karl Schleunes's Schooling and Society: The Politics of Education in Prussia and Bavaria, 1750-1900 (1989) or to the more detailed study by John Kulczycki, School Strikes in Prussian Poland, 1901-1907 (1981).

James C. Albisetti

University of Kentucky

\section{Basil H. Johnston. Indian School Days. Toronto: Key Porter Books, 1988. Pp. 250, $\$ 24.95$ cloth.}

The literature on the history of native education in Canada is sparse at best. Most of the work done to date focuses on residential institutions, examining their operations from the perspectives of missionaries and government officials. Basil Johnston's Indian School Days adds another dimension-that of the children who underwent the often terrifying experience of the white man's schooling.

St. Peter Claver's Indian Residential School (known as Garnier after 1945), located in the village of Spanish on the northern shore of Lake Huron, was run by the Jesuit Fathers with the help of subsidies from the federal Department of Indian Affairs. 